\title{
The Role of Fire in the Posthumous Customs of Podlachia on the Border of Poland and Belarus
}

\section{Joanna Wawrzeniuk}

In this article, I would like to describe the role of fire in the customs of All Souls' Day in the Easter period called przewody or radunica. The burning of the fires most commonly took place overnight at home and in cemeteries to illuminate the way for the transmigration of souls so they would not harm the living. The reflection of special respect for fire is known from the funeral rites from the area of Podlachia in the Middle Ages. It also served as a basic element of the ritual related to cyclical visits to the dead, as evidenced by the remains of charcoals or ash. Different kind of sources from the Middle Ages and modern times, from the region of eastern Poland (Podlachia and Belarus, in particular) shall be used to confirm that the rite lasted for many years.

KEYWORDS: fire, Slavs, All Souls’ Day, Przewody, Radunica, Eastern Poland, cemeteries, from Middle Ages to Present Times

Fire served men from birth to death. It was used in annual customs, in everyday life, as well as in festivities. Fire, as the main element of the hearth, made the community of family or kin. It was also a symbol of life and existence, and an altar - an intermediary between the group of fire-users and the spirits of their ancestors, and the entire superficial world in general (Ciszewski 1903: $177 \mathrm{ff}$.). In Christian tradition, it appears as a symbol of Christ, a symbol of his power and justice. Fire is viewed by Christians, the Chinese, and the Hebrews as being a symbol of divinity. In Christianity, fire can also be symbolic of religious zeal and martyrdom (Forstner 1990: 74; Lurker 1994: 127).

Fire in its different meanings was used in a special moment in the life of a community, namely in the All Souls' Day customs. It was a family 'holiday' associated with the cult of long-gone ancestors or simply with dead relatives. In Christian tradition, special devotions called 'parents' Saturdays' were also held on days dedicated to remembering the dead to observe the same goal. All these rituals served the fulfilment of duties towards the dead. The essence of All Souls' Day rites was the 'exchange of gifts' between the living and the dead, the mutual provision of certain services. The dead received what 
they lacked in 'that world', while the living received a guarantee of further prosperity for their homes and farms (Grochowski 2009: 26).

The area that interests me most is primarily Podlachia and the Polish-Belarusian borderland. In these considerations, the starting point will be a presentation of written sources from the Middle Ages and modern times, followed by archaeological sources from this region, as well as the available written sources regarding the periods in question. I will attempt to prove the validity of these beliefs by presenting ethnographic materials.

The attestation of this type of behaviour includes texts from the $11^{\text {th }}$ century (Tale of Bygone Years), in which there is a passage about rusalia and a trizna - feast on the grave of the deceased (The Russian Primary Chronicle 1953: 80, 86, 147; Powieść 1999: 45, 54, 133; Labudda 1983: 37-38). In The Chronicle of the Czechs by Cosmas of Prague from the $12^{\text {th }}$ century, the author discusses games that took place on crossroads and the putting on of masks during those games (The Chronicle of Czechs 2009: 182; Kosmasa 1968: 92; Fischer 1921: 386-387. Finally, in the document of Henry the Bearded, from 1229 , there is a festival called radunica in Silesia).

In the days of All Souls', lights were also lit, all night long, at home and in the cemetery (Zawistowicz 1925: 856-858). The souls needed them to warm up; the lights showed them the way to come and return to the afterlife and helped the living prepare the dishes for the dead (Renik 1986: 31). There was also a belief that souls who came from a muddy road first had to wash and clean themselves, which is why people prepared for them a bath in the bathhouse. From the compilation known as The Divine Liturgy of Our Holy Father John Chrysostom from the $14^{\text {th }}$ century, we learn about the construction of bridges for the dead, which may reflect the custom of building special wooden footbridges through rivers and streams. A human footprint was carved on the footbridges; afterwards, it was believed to be an 'All Souls' footbridge', which reminded the living about the obligation to sigh for the souls of the deceased every time they crossed it. After the end of the rite, it was necessary to destroy such a footbridge (Mansikka 1922: 174ff; Łowmiański 1986: 134ff; Bylina 1999: 18). From south Ukraine, there is information about a small board placed on the vessel, as it was believed, for the child Jesus to reset on after he had emerged from water (Moszyński 1967: 358). As reported in the Trzemeszno Sermons (written by Michał of Janów in the 15th century,) people burned so-called 'gromadki' [clusters/bunches] on Holy Thursday on graves, believing that the souls of the dead will come to warm themselves (Moszyński 1967: 598).

In pre-Christian times the role of fire in funeral rituals was primarily related to cremation and certainly in Podlachia, in the light of archaeological materials, this custom prevailed from the $8^{\text {th }}$ century (most fully in the $11^{\text {th }}$ century) and survived at least until the $14^{\text {th }}$ century. This type of burial is mainly related to barrows from forest areas (Białowieża Forest, Knyszyn Forest), from the archaeologically best-examined area of the Drohiczyn Upland, and the Southern Podlachia region (between the Bug and Krzna Rivers) (Kalaga 2006; Dzik 2012: 610ff).

Single graves of such kind are known from Zawyki, Doktorce, and Średzińskie from Suraż municipality, a part of the Bielsk Plain. The dead were usually cremated outside 


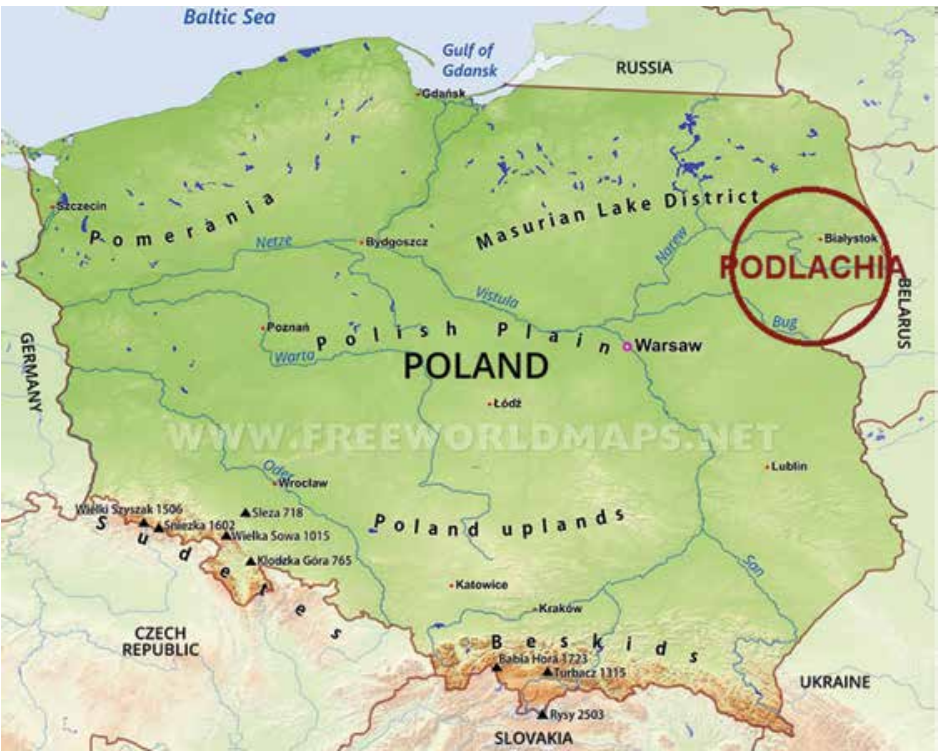

Fig. 1. Map of Poland with Podlachia region (elaborated by J. Wawrzeniuk)

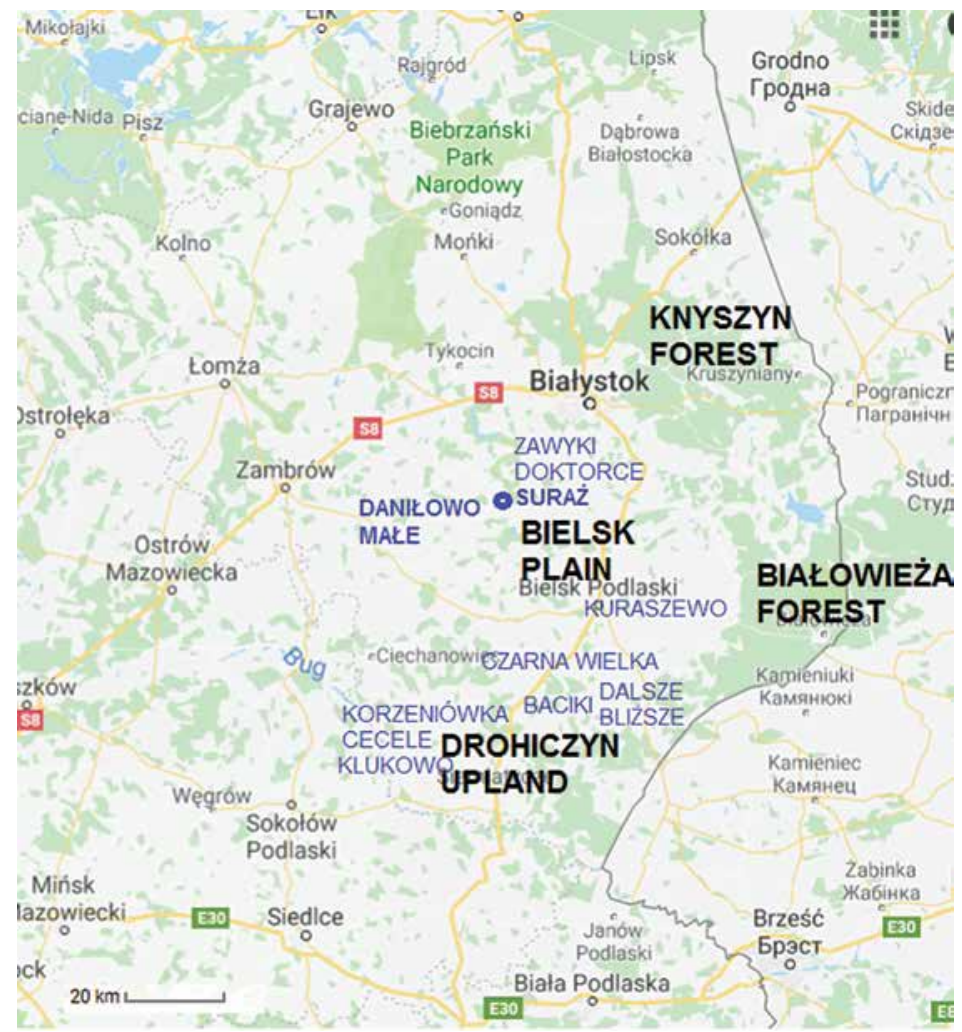

Fig. 2. Map of Podlachia with archaeological sites mentions in the article (elaborated by J. Wawrzeniuk) 
their place of burial, which was primarily discovered in the areas between the central part of the Bug River and the upper Narew River.

Burnt bones were found in various places on the earthworks of barrow: on the floor, on the ceiling, on its various levels, or in the pit under the earthwork. A characteristic feature of most objects is the presence of strongly burnt bones, recorded in a very small number, up to several dozen pieces. This is probably to some extent the result of some not quite known funeral practices, which allowed only a part of the bones left after burning the deceased to be deposited in the grave. Strong fragmentation and burning of the bones are undoubtedly a result of cremating the bodies at high temperature.

In the cremation rite, fire was used as early as during the burial site's preparation. For this purpose, preparing a place for an earthwork included cleaning it, burning the vegetation, or possibly scattering the burnt remains and ash from the furnace, which were purposely brought to the place of the future grave. These could be ordinary preparatory works or ritualistic activities (Sikora 2002: 342).

Burnt remains and ashes could be brought to the place of the future grave burnt bones or vessel fragments were sometimes also present in this layer. They could be the remnants of a hearth fire or symbolically burnt belongings of the deceased. Traces of other fire-related treatments such fireplaces ringed by stone (containing, among other things, burned animal bones) were discovered in barrow 10 from Baciki Dalsze and barrow 6 from site 2 in Klukowo. (Dzik 2015: 128).

Sometimes individual pieces of charcoal or small clusters of them were discovered in higher parts of earthworks or in the so-called barrow's ditches. Remains of this type could come from some rituals directly related to All Souls' Day. It is also possible to find traces of old burial rituals (like fireplace remains, animal bones, or fragments of vessels) in flat graves with cremated human remains, although they are, as researchers say, much harder to grasp. Crematory graves rarely contained burial gifts, which were usually of poor quality, burned, or deliberately destroyed.

The introduction of inhumation, a new habit of burying the dead, was visible in burial mounds, in flat graves, often marked on the surface by layers of stones, which were called 'graves in stone enclosures' in the archaeological literature. The common feature of the skeletal rite in Podlachia's necropolises was placing the dead inside graves in an upright position, on their backs, and with their heads facing west. In many cemeteries from the $11^{\text {th }}$ and $12^{\text {th }}$ centuries, there is a visible relationship between the burial's geographical orientation and the sex of a deceased person: men were frequently placed with heads facing east, while women faced west (Januszewski 1967: 307-314; Zoll-Adamikowa 1971: 46-47). In the interpretations of placing the dead towards the west, attention is paid to the Sun's location and the relation with the cult of the Sun (Lega 1930: 375; Rajewski 1937-1939: 55).

Considering written sources, the most frequently recorded orientation is associated with the location of the Slavic world of the dead in the West. In this view, it would be a pre-Christian custom. In contrast, a relationship between westward orientation and the Christian funeral rite, according to which the dead should be buried facing east, is indicated (Gąssowski 1950: 157-158; Nadolski et al. 1959: 18). 
The dead were certainly buried in clothing along with their decorations. The most common decorations in women's graves were necklaces made from glass beads, bronze or rarely silver pendants, silver beads of various shapes, and crosses and very often temple rings or earrings. Knives and spindle whorls were sometimes put into women's graves. Men's graves were mostly equipped with everyday objects: knives, whetstones, flints. Only in the cemetery in Daniłowo Małe some weapons (a spearhead, iron axes, iron arrowheads, and wooden buckets in which food could originally be stored) were found in several men's tombs (Krasnodębski 1999). The grave equipment proves connections between the inhabitants of the Narew region and the neighbouring Masovians, Eastern Slavs, and Balts.

It is possible to find traces of hearths and clumps of charcoals in the shape of a more or less regular oval within Early Medieval skeleton cemeteries. Burning fires within flat graves or near them is a practice confirmed for both unchambered and shallow tombs, with both cremation and inhumation burials. In Podlachia, for example, on Drohiczyn Upland, it was rather a rare custom that probably disappeared in the $12^{\text {th }}$ century. Exceptionally, on two cemeteries in Kuraszewo (Bielsk Plain), the fireplaces were discovered in the vast majority of objects, including those from the $12^{\text {th }}$ and the first half of the $13^{\text {th }}$ century (Dzik 2015: 128).

The collected archaeological material allows the assumption that fires in cemeteries were burnt both during the placing of the body in the grave and, in later periods, on the days of rite-observance (Wrzesiński 1999: 265; Wrzesińska, Wrzesiński 2002). This is confirmed by the presence, next to objects directly related to the deceased, of charcoal, stones, and animal bones inside the burial pit. Sometimes they could not have a relationship to the grave. Remains of this type were found near the skull or chest, less frequently near the legs. These remains were associated with fires burnt directly on the graves of the dead, as well as inside the pit, where, as it is supposed, they were lit when the body was already lying in the grave. In the Drohiczyn Upland, the remains of charcoal and ash were even recognised as a reminiscence of the cremation funeral rites (Gozdowo, site B, a cemetery from the $13^{\text {th }}$ century, Mazovia) (Musianowicz, 1950/51, Wrzesiński 1999: 157). Sometimes, the fired could be burned near the corps in the case of strong winds or to repel predatory animals (Miśkiewicz 1969: 256).

In turn, in the Orthodox Christian tradition in Eastern Poland, fire was used as one of the elements of rituals related to the dead during the so-called dziady - feasts celebrated several times a year (Tokarev 1957: 37-38). In ethnographic records, the spring and autumn seasons were of particular importance. Other days of remembrance and prayer for the dead are the third, ninth, and fortieth day after death, as well as the first and subsequent anniversaries. In literature, the autumn holidays were called $d z i a d y$ and the spring holidays associated with the cycle of Easter were known in the basic form as Radunica or Prowody. The etymology of Radunica is associated with the Lithuanian raudati (to cry, sob), rauda (crying for the dead), and Prowody (from provoditi) to lead, carry; it was probably related to carrying the souls of the dead from the world of the living to the dead world, which is the final stage of the 'All Souls' Day rite.' Nowadays, the frequently used term is pominanje (Androsiuk 1994: 9). 
The main ceremonies took place at the cemetery, on a Thursday after Easter. Visits to the cemetery did not happen everywhere at the same time. In Podlachia, as well as in the Polish and Belarus Polesia, All Souls' Day rites could be held from Easter Sunday to Thursday. The main day of the first spring All Souls' celebrations in Podlachia, among Eastern Slavs in Belarus and Ukraine, as well as in Russia, was the first Tuesday after the Divine Mercy Sunday, or the ninth day after Easter (Androsiuk 1994: 9).

The most comprehensive information about the elements of this holiday can be found in the descriptions of radunica from the beginning of the $20^{\text {th }}$ century. They consisted of:

- prayers for the dead,

- bringing food to the graves of the dead,

- singing songs,

- crying and despairing for the dead,

- games

- rolling eggs, playing bitki (which involved hitting the other player's Easter Egg with one's own),

- eating a meal on the graves together with the invited ancestors,

- gifting beggars with bread, cake, sausage, lard, eggs, money (Zmitrovsky Dziady in Belarus - a few customs related to feasting) (Klinger 1926: 72; Pigoń 1966: 68-69; Kotovič, Kruk 2008: 352-353). Numerous games and jostles in a cheerful atmosphere were an important element of such holidays (Pietkiewicz 1931: 30; Renik 1986: 32).

Nowadays, a still important part of przewody is decorating the graves with flowers and ribbons, bringing eggs and bread, on Belarus also sweets on the plates, forks, and glasses with vodka, eating a ritual meal with family members after prayers for the dead and mass in the church. Numerous ethnographic messages describing rites during the so-called pominki from the late $19^{\text {th }}$ and early $20^{\text {th }}$ centuries prompted field research. Four rural cemeteries located in the Białowieża Forest region, both sides of the Polish-Belarusian border, were selected for the research experiment carried out in spring 2016. The aims were also checking the vitality of the festivity, determining the activities associated with it and learning how the holiday is perceived by the rural Orthodox population. As a result, these customs continue to be practised very solemnly at some cemeteries in Poland. In contrast, in Belarus, celebrating Radunica is becoming less and less popular because the Church banned the practice. In some places, visiting graves and praying for the dead take place on Pentecost (a feast blessing herbs, which is celebrated in the Orthodox Church on the fiftieth day after Easter).

The ceremony associated with the dead was usually related to the two principles described by Claude Lévi-Strauss, namely the 'kind dead' and 'angry dead. Sacrificial feasts probably took place by these fires both during the burial and later, and the explored artefacts should be treated as ritual offerings (Lévi-Strauss 1992: 229; Szyjewski 2003: 210). Researchers think that burning fires next to and inside the burial pits was tolerated during the formation of the organised church. 'Perhaps in this way tradition - ritualistic purification of the pit, driving away all evil, and finally trizna - was reconciled with a new 


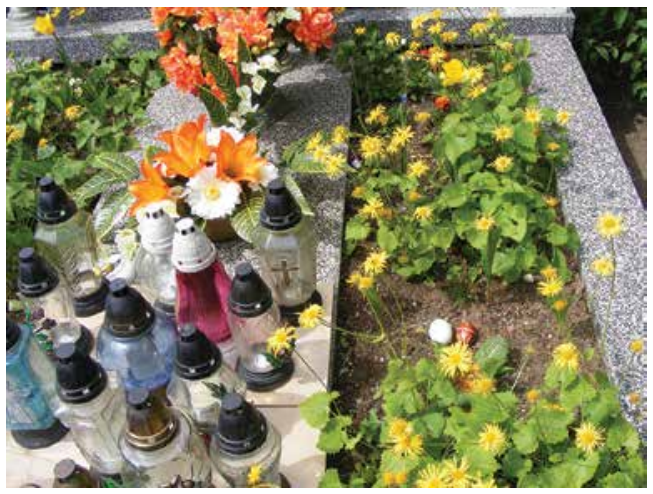

Fig. 3. Candles and eggs on the grave. Łosinka, Podlachia, Białowieza Forest Region, Poland (photo J. Wawrzeniuk)

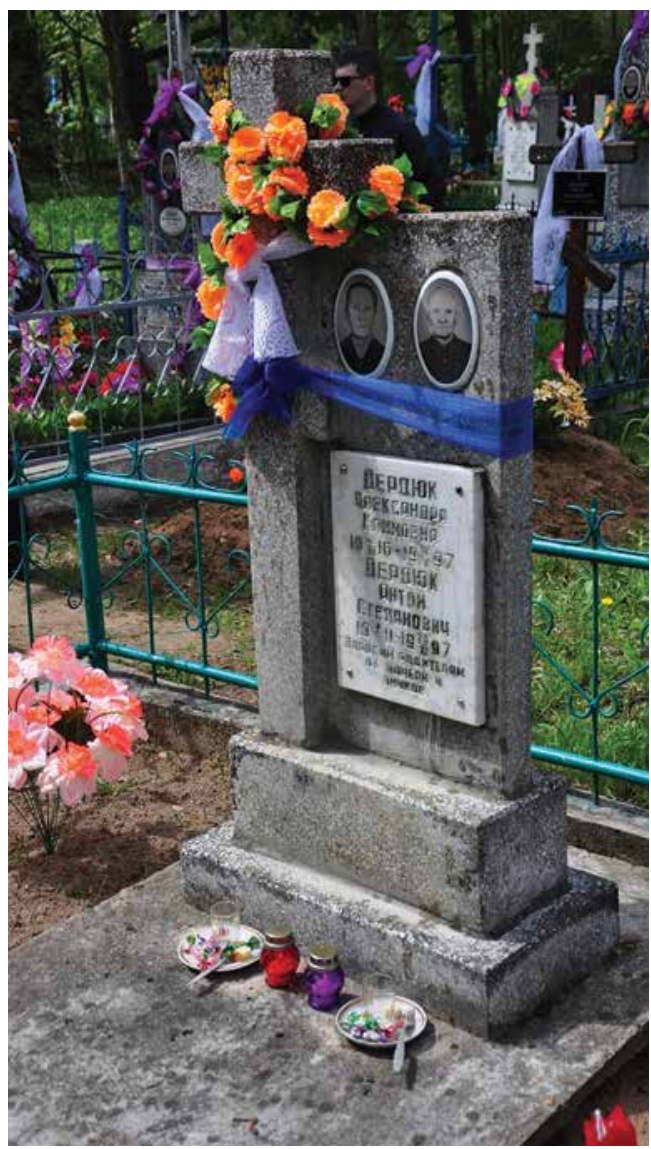

Fig. 4. Candles, sweets, forks, glasses and the plates on the grave. Zarečany, Białowieza Forest Region, West Belarus (photo E. Zajkovski)

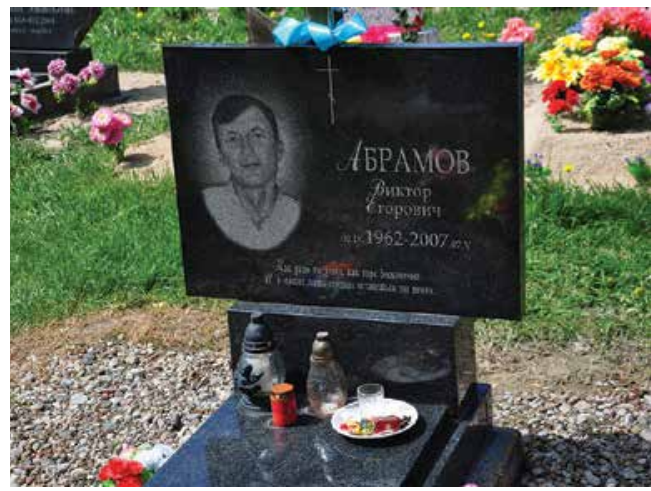

Fig. 5. Candles, sweets and the glass on the plate, on the grave. Vojskaă, Białowieza Forest Region, West Belarus (photo E. Zajkovski)

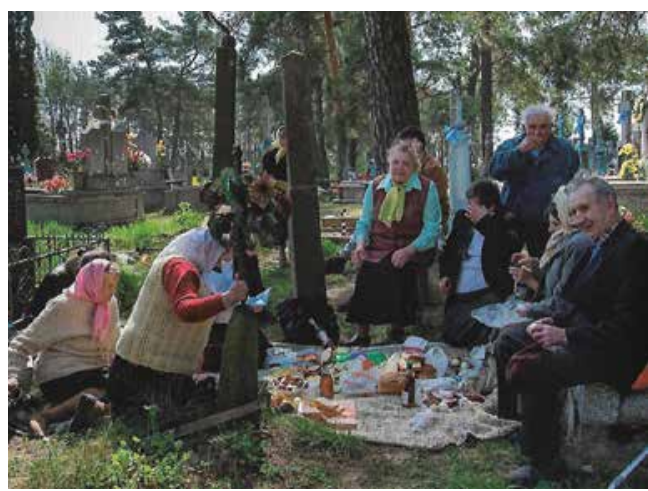

Fig. 6. Memorial meal by the graves - 2011, Czyże, Podlachia, Białowieza Forest Region, Poland (photo A. Gaweł)

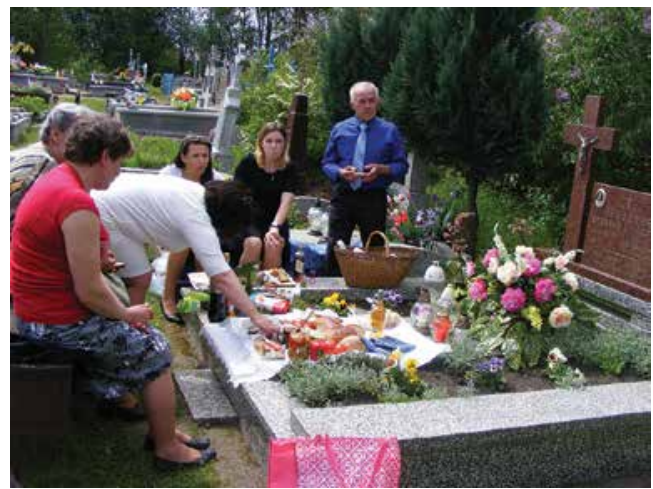

Fig. 7. Memorial meal by the graves - 2016, Łosinka, Podlachia, Białowieza Forest Region, Poland (photo J. Wawrzeniuk) 
religion, which tolerated (for some time) the presence of fire in cemeteries (Wrzesińska, Wrzesiński 2002: 158).

Throwing coals and ash from bonfires and fireplaces into burial pits served as a protection against diseases and what was considered impure and also against evil spirits. Mostly charcoal and ash were discovered at the burial level or directly below it (Ciszewski 1903: 56-74). They could be the remnants of the deceased. From Kamionka (Ropczyce region, Carpathians Foothills) recorded in the second half of the 19th century: 'if a deceased loved any thing in the life, then it was burned and ash brought to his grave' (Charchut 1964: 20).

According to many researchers, burning fires near graves has survived to date, albeit in a different form. We can find analogies in lighting candles during All Souls' Day or in ordinary visits at cemeteries. A candle - an offering - is lit during every visit and before the church service. Such a fire symbolises remembering the deceased. The flame-induced light has a purifying sense; it is a symbol of the essence, the durability of Christian faith; lit on the grave, it is a symbol of eternity and resurrection. Contacting the souls returning for All Soul's Day was necessary, and it could support the living in further terrestrial existence (Renik 1986: 32).

Finally, a story in which a dying old man asks for some fire from his 'holy' flint (from Polesier) may be a reminiscence of old beliefs. This symbolic spark would illuminate for him the way to the afterlife (Moszyński 1967: 493).

The valorisation of the fire in Podlachia and the Polish-Belarusian borderline survived despite the religion changing. It should be noted that fire is an important element of faith in the purifying power of ash, which is a material trace of purification through fire. The Bible verse is well known: "For you are dust and to dust you shall return" (Genesis 3:19). Prayers related to the sacrifice of ash date to the $10^{\text {th }}$ century.

\section{REFERENCES}

Androsiuk, Nina, 1994: „Przewody” na Białostocczyźnie”. Czasopis 5 (41), Białystok, 9.

Bylina, Stanisław, 1999: Wierzenia dawnych Słowian: Stanisław Bylina, Kultura ludowa Polski $i$ Stowiańszczyzny średniowiecznej. Łowicz, Mazowiecka Wyższa Szkoła Humanistyczno-Pedagogiczna, 11-53.

Charchut, Edward, 1964: Doroczne zwyczaje we wsiach Kamionka i Ruda, pow. Ropczyce. Manuscript in The Etnographic Museum in Rzeszów archive, no 630. volume 112. Rzeszów.

Ciszewski, Stanisław, 1903, Ognisko. Studyum etnologiczne. Kraków: Nakładem Akademii Umiejętności.

Dziewulski, Władysław, 1964: Postępy chrystianizacji i proces likwidacji pogaństwa $w$ Polsce wczesnofeudalnej. Wrocław: Zakład Narodowy im. Ossolińskich.

Dzik, Michał, 2015: Przemiany zwyczajów pogrzebowych w międzyrzeczu Bugu i górnej Narwi $(X I-X V$ w.). Volume 2. Rzeszów: Oficyna Wydawnicza „Zimowit” sp. z o.o.

Fischer, Adam, 1921: Zwyczaje pogrzebowe ludu polskiego. Lwów: Zakład Narodowy im. Ossolińskich.

Forstner, Dorothea, 1990: Świat symboliki chrześcijańskiej. Warszawa: Instytut Wydawniczy PAX. 
Gąssowski, Jerzy, 1950/51: Wczesnośredniowieczne cmentarzysko szkieletowe w Radomiu. Wiadomości Archeologiczne 17, Warszawa, 305-324.

Grochowski, Piotr, 2009: Dziady. Rzecz o wędrownych żebrakach i ich pieśniach. Torun: Wydawnictwo Naukowe Uniwersytetu Mikołaja Kopernika.

Januszewski, Józef, 1967: Rola słońca w usytuowaniu grobów wczesnośredniowiecznych w Końskich. Acta Universitatis Wratislawiensis. Studia Archeologiczne 2, 307-314.

Kalaga, Joanna, 2006: Ciałopalny obrzqdek pogrzebowy w Międzyrzeczu Liwca, Bugu i Krzny. Warszawa: Instytut Archeologii Uniwersytet Warszawski.

Klinger, Witold, 1926: Obrzędowość ludowa Bożego Narodzenia. Jej początek i znaczenie pierwotne. Poznań: Fiszer i Majewski.

Kotovič, Oksana; Kruk Janka, 2008: Zol'otyje pravila narodnoj ku'ltury. Minsk: Adukacyâ i vyhavanne.

Krasnodębski, Dariusz, 1999: Ratownictwo archeologiczne na trasie budowy gazociagu jamajskiego we wschodniej części województwa podlaskiego. Biuletyn Konserwatorski Województwa Podlaskiego 5, 215-217.

Labudda, Alfons, 1983: Liturgia pogrzebu w Polsce do wydania Rytuatu Piotrowskiego (1631). Studium historyczno-liturgiczne. Warszawa: Akademia Teologii Katolickiej.

Lévi-Strauss, Claude, 1992: Smutek tropików/Tristes tropiques. Łódź: Wydawnictwo Opus.

Lurker, Manfred, 1994: Przestanie symboli w mitach, kulturach i religiach/Die Botschaft der Symbole in Mythen, Kulturen und Religionen, Kraków: Znak.

Łęga, Władysław Jan, 1930: Kultura Pomorza we wczesnem średniowieczu na podstawie wykopalisk. Toruń: Nakładem Towarzystwa Naukowego.

Łowmiański, Henryk, 1979: Religia Stowian i jej upadek (w. VI-XII). Warszawa: Państwowe Wydawnictwo Naukowe.

Mansikka, Viljo Johannes, 1922: Die Religion der Ostslaven. I Quellen. Folklore Fullow Communications, No 43, Helsinki: Suomalainen Tiedeakatemia.

Miśkiewicz, Maria, 1969: Wczesnośredniowieczny obrządek pogrzebowy na płaskich cmentarzyskach szkieletowych w Polsce. Materiały Wczesnośredniowieczne 6, 241-293.

Moszyński, Kazimierz, 1967: Kultura ludowa Stowian. Vol. II: Kultura duchowa: Part. 1. Warszawa: Książka i Wiedza.

Musianowicz, Krystyna, 1950/51: Cmentarzysko i osada wczesnohistoryczna w Gozdowie, pow. Sierpc. Wiadomości Archeologiczne 17, 251-302.

Nadolski, Andrzej; Abramowicz, Andrzej; Poklewski, Tadeusz, 1959: Cmentarzysko z XI w. w Lutomiersku pod Łodzią". Acta Archaeologica Universitatis Lodziensis 7. Łódź: Łódzkie Towarzystwo Naukowe; Wrocław: Zakład Narodowy im. Ossolińskich.

Pietkiewicz, Czesław, 1931: Umarli w wierzeniach Białorusinów. Part. 2. Pamiętnik Warszawski 3, 70-89.

Pigoń, Stanisław, 1966: Wołyńskie przewody. Wiosenne święto zmarłych, Stanisław Pigoń Drzewiej i wczoraj. Wśród zagadnień kultury i literatury. Kraków: Wydawnictwo Literackie, 61-75.

Rajewski, Zdzisław, 1937-1939: Wielkopolskie cmentarzyska rzędowe. Przeglad Archeologiczny $6,28-85$.

Rauhut, Lechosław, 1971: Wczesnośredniowieczne cmentarzyska w obudowie kamiennej na Mazowszu i Podlasiu. Materiały Starożytne i Wczesnośredniowieczne 1, 435-653.

Renik, Krzysztof, 1986: O kontaktach ze zmarłymi-ludowe wyobrażenia. Polska Sztuka Ludowa 40(1-2), 31-36. 
Sikora, Przemysław, 2002: Kurhan relikt tradycji pogańskiej w świecie chrześcijańskim wczesnego średniowiecza na przykładzie obszaru Polesia”. Jacek Wrzesiński (ed.) Popiót i Kość. Funeralia Lednickie. Spotkanie 4. Sobótka-Wrocław: Muzeum Ślężańskie w Sobótce, 339-351.

Szyjewski, Andrzej, 2003: Religia Stowian. Kraków: Wydawnictwo WAM.

Tokarev, Sergei Aleksandrovič, 1957: Religôznyâ verovaniâ vostočnoslavânskih narodov (XIX-načala $X X$ v.). Moskva: Nauka.

Wrzesińska, Anna; Wrzesiński, Jacek, 2002: Z problematyki węgli drzewnych w jamach grobowych - częstość występowania węgli drzewnych w grobach wczesnośredniowiecznego cmentarzyska „Mały Skansen”. Studia Lednickie 7, 143-161.

Wrzesiński, Jacek, 1999: Cmentarzysko wczesnośredniowieczne jako centralne miejsce praktyk religijnych i odbicie lokalnej struktury społecznej-przykład dziekanowicki. Sławomir Moździoch (ed), Centrum i zaplecze we wczesnośredniowiecznej Europie Środkowej. Spotkania Bytomskie III. Wrocław: Werk, 257-271.

Zawistowicz, Kazimiera, 1925: Momenty zaduszkowe w obrzędowości Świąt Bożego Narodzenia. Wiedza i Życie 6, 849-859.

Zoll-Adamikowa, Helena, 1971: Wczesnośredniowieczne cmentarzyska szkieletowe Małopolski. Part 2. Analiza. Wrocław, Warszawa, Kraków, Gdańsk: Zakład Narodowy im. Ossolińskich. Wydawnictwo Polskiej Akademii Nauk.

\section{SOURCES}

Bible/ Bible Version/ English Standard Version/ Genesis/ Genesis $<<$ https://www.biblestudytools. com/esv/genesis/3.html $\gg$ - accessed 01/03/2019

Kosmasa Kronika Czechów., 1968. translation Maria Wojciechowska., Warszawa: Państwowe Wydawnictwo Naukowe.

Cosmas of Prague. 2009, The Chronicle of the Czechs. Wolverton, Lisa, ed. Washington, D.C.: Catholic University of America Press.

Powieść minionych lat, 1999, translation Franciszek Sielicki, Warszawa ,Warszawa, Kraków: Zakład Narodowy imienia Ossolińskich.

The Russian Primary chronicle: Laurentian text. 1953. Hazzard Cross, Samuel; Sherbowitz-Wetzor, Olgerd, eds. Cambridge: The Mediaeval Academy of America. 


\section{ROLA OGNIA W ZWYCZAJACH ZADUSZKOWYCH NA PODLASIU I POGRANICZU POLSKO-BIALORUSKIM \\ JOANNA WAWRZENIUK \\ $\infty$}

W artykule opisuję rolę i funkcję ognia w zwyczajach zaduszkowych związanych z powinnościami wobec zmarłego na obszarze wschodniej Polski i pograniczu polsko-białoruskim. W niniejszych rozważaniach zostaną wykorzystane źródła archeologiczne z okresu średniowiecza i czasów nowożytnych, dostępne źródła pisane, dotyczące omawianych okresów oraz analogie etnograficzne. Będzie to więc próba analizy tradycyjnego zwyczaju poprzez wskazanie jego żywotności, mimo niewątpliwie zaistniałej już transformacji obrzędu. W tekstach źródłowych takich jak na przykład: Powieść minionych lat, dokumencie Henryka Brodatego z 1299 roku, Kronice Czechów Kosmasa, kompilacji znanej jako Słowo Świętego Ojca Jana Złotoustego czy Kazaniach Trzemeszneńskich z XV wieku Michała z Janowa znajdujemy również opisy podobnych przedchrześcijańskich zwyczajów.

W źródłach archeologicznych odbicie szczególnego poszanowania ognia ma związek przede wszystkim z kremacją, ale znajduje swoje odbicie również $\mathrm{w}$ paleniu ogni przy grobach szkieletowych, a także w obrządku birytualnym na cmentarzyskach z terenu Podlasia. Ogień wykorzystywano do przygotowania miejsca pochówku czy oczyszczania samego grobu lub jamy grobowej. Służył on również jako podstawowy element obrzędu cyklicznego odwiedzania zmarłych, o czym świadczą takie pozostałości, jak węgle drzewne czy popiół.

Wspominanie zmarłych to rodzaj rodzinnych ,świąt” związanych z kultem dawnych przodków lub po prostu z nieżyjącymi już krewnymi. W tym celu zamawiano także specjalne nabożeństwa $\mathrm{w}$ dni poświęcone pamięci zmarłych nazywane „roditelskije soboty”. Wszystkie te obrzędy służyły spełnianiu obowiązków wobec zmarłych i były pewnego rodzaju „wymianą darów” pomiędzy żywymi a zmarłymi. Na terenie wschodniej Polski, według danych etnograficznych, oprócz wspominania i modlitwy za zmarłych w 4, 9, 40 dniu, 1 roku po śmierci, zachowały się zwyczaje związane z obrzędami zadusznymi w okresie Wielkanocnym - ,dziady” wiosenne i listopadowym - „dziady” jesienne. Najbardziej rozbudowane były obrzędy wiosenne zwane na terenie Podlasia najczęściej terminem przewody-prowody a na terenie Białorusi Radunica. Na Podlasiu, a także na Polesiu obchody zaduszne mogły się odbywać od niedzieli Wielkanocnej do czwartku. Głównym dniem pierwszych wiosennych zaduszek na Podlasiu, u Słowian Wschodnich na Białorusi, na Ukrainie, jak również w Rosji uważano wtorek po Niedzieli Przewodniej, czyli dziewiąty dzień po święcie Wielkiej Nocy. Przynoszono wtedy na groby pokarmy, śpiewano pieśni, płakano i lamentowano za zmarłymi, grano w różne zabawy oraz palono ogień. Palenie ogni najczęściej odbywało się przez całą noc, w domu i na cmentarzach. Miały one oświetlać drogę wędrówki dusz, ogrzewać i wskazywać miejsce przygotowanych dla nich pokarmów. Liczne przekazy 
etnograficzne opisujące zachowania podczas tzw. pominek z końca XIX wieku i początku XX wieku sprowokowały do przeprowadzenia badań terenowych. Do eksperymentu badawczego, przeprowadzonego wiosną 2016 roku, wybrano cztery cmentarze wiejskie w regionie Puszczy Białowieskiej zlokalizowanych po obu stronach granicy polsko-białoruskiej. Celem badań było także sprawdzenie żywotności święta, określenie czynności z nim związanych oraz sprawdzenie w jaki sposób święto jest postrzegane przez współczesną prawosławną ludność wiejską. W rezultacie stwierdzono, że zwyczaj przewodów-prowodów kultywowany jest jeszcze na niektórych cmentarzach w Polsce bardzo uroczyście. Natomiast na Białorusi przez zakazy Cerkwi staje się coraz mniej popularne celebrowanie święta Radunicy. W niektórych miejscowościach odwiedzanie grobów i modlenie się za zmarłych odbywał się w święto Zesłania Ducha Świętego -potocznie znane jako Zielone Świątki (święto poświęcenia ziół, które jest obchodzone w kościele prawosławnym w pięćdziesiąty dzień po Wielkanocy).

Palenie ogni przy grobach to zwyczaj ciaggle obecny, chociaż oczywiście zmodyfikowany. Analogie znajdujemy w zapalaniu zniczy w czasie świąt zadusznych lub w zwyczajnym przychodzeniu na cmentarze. Świeczkę - ofiarę zapala się przy każdej wizycie i przed nabożeństwem w cerkwi. Taki ogień to pamięć o zmarłym. Światło wywołane płomieniem ma znaczenie oczyszczające, oznacza istotę, trwałość wiary chrześcijańskiej, zapalone na grobie jest symbolem wieczności i zmartwychwstania.

Joanna Wawrzeniuk, Ph.D., Associate Professor, Institute of Archaeology, Faculty of Historical Sciences, Cardinal Stefan Wyszyński University in Warsaw, Poland, Wóycickiego 1/3, building 23, 01-938 Warsaw, Poland, j.wawrzeniuk@uksw.edu.pl 